\title{
Effect of Smartphone Applications for Aural Habilitation in Cochlear Implanted Children: Improvement for Auditory Memory Skills
}

\author{
Youngmee Lee', Seulgi Lee ${ }^{2,3}$ \\ ${ }^{1}$ Department of Communication Disorders, Tongmyong University, Busan, Korea \\ ${ }^{2}$ Department of Speech-Language Therapy \& Aural Rehabilitation, Graduate School of Health and Welfare, Woosong University, Daejeon, Korea \\ ${ }^{3}$ Donga Auditory Habilitation Center, Busan, Korea
}

\section{스마트폰 어플리케이션을 이용한 중재가 인공와우 아동의 청각기억에 미치는 영향}

이 영 미 $\cdot$ 이 슬 기 ${ }^{2,3}$

동명대학교 언어치료학과 ${ }^{1}$, 우송대학교 보건복지대학원 언어청각재활학과, ${ }^{2}$ 동아와우청각언어센터 ${ }^{3}$

\begin{abstract}
Purpose: The purpose of this study was to investigate the effects of aural habilitation using the smartphone applications of auditory memory skills for children with cochlear implants. Methods: Three children with cochlear implants (CIs) between the ages of 3 and 8 years participated in this study. The children attended the intervention using the smartphone applications once a week for 5 weeks. We evaluated their auditory memory skills before and after intervention, and analyzed the data using a one-group pretest and posttest design. The child's mother attended the survey for evaluating the educational effectiveness and satisfaction from the aural habilitation using the applications. Results: There were significant accuracy increases in the categorical items of auditory memory tasks. The intervention effect was not significant for auditory memory accuracy in the non-categorical items. There were individual differences in mother's perceived educational effectiveness and satisfaction with the intervention using the applications. Conclusion: The current study suggests that aural habilitation using the smartphone applications is effective and useful in improving auditory memory skills for children with Cls.
\end{abstract}

Key Words: Aural habilitation, Smartphone application, Auditory memory, Cochlear implants, Children.

Received: February 6, 2017 / Revised: March 15, 2017 / Accepted: April 2, 2017

Correspondence: Youngmee Lee, Department of Communication Disorders, Tongmyong University, 428 Sinseon-ro, Nam-gu, Busan 48520, Korea Tel: +82-51-629-2135 / Fax: +82-51-629-2019 / E-mail: ymlee3060@gmail.com

\section{INTRODUCTION}

국내외에서는 신생아청각선별검사로 난청이 진단되면, 영아 는 청각장애 유형과 청력손실 정도에 따라 적절한 보청기를 착 용하고 말-언어 발달을 위한 청능재활(aural habilitation)에 참 여한다. 이때, 청각장애 영아의 청력이 고도(severe) 이상이고 보청기를 착용해도 말-언어의 발달이 미비한 경우에는 인공와 우이식(cochlear implantation)의 대상이 되며, 인공와우이식 을 통해 구어 의사소통(oral communication) 발달에 필요한 유용한 청력을 가지게 된다(ASHA, 2017; Blamey et al., 2001;
Cole \& Flexer, 2011). 선행 연구(Houston \& Miyamoto, 2010; James et al., 2008; Lee et al., 2012)에서는 청각장애 아동의 인 공와우이식 연령이 어릴수록 더 나은 말지각(speech perception), 말-언어, 의사소통, 학업 성취를 보인다고 하였다. Burkholder \& Pisoni(2003)는 인공와우이식 연령만으로 인공와우 아동의 술 후 수행력을 설명할 수 없다고 언급하면서, 조기에 인공와우이식을 받더라고 청각장애 아동의 수행력 발달에 개 인 간 차이가 크다고 보고하였다. 즉, 인공와우 아동 중에서 일 부는 정상청력의 또래 아동과 비슷한 수준의 말-언어 발달을 성취하기도 하지만, 다른 일부는 말-언어 발달에 지체(delay), 
장애(disorder)를 경험하면서 통합교육 환경에서 또래와의 적절 한 상호작용과 학업 성취에 어려움을 겪고 있기도 하다.

인공와우 아동은 연령에 맞는 말-언어 발달을 성취하거나 발달 차이를 최소화하기 위해서 술 후부터 듣기(listening) 중 심의 청능재활에 부모와 함께 참여한다. 청능재활 전문가는 인 공와우 아동의 개인 요인(예: 인공와우이식 연령, 내이기형 유 무, 중복장애 유무 등)과 수행력 발달 수준을 고려하여, 대상 아동 맞춤식의 장단기 목표와 세부 활동을 계획한다(Lee, 2008b; Lee, 2016). 말-언어 습득이 완성된 후천성 농 성인의 경우 듣기 중심으로 청능재활 프로그램이 진행되는 것과 달리, 인공와우 아동의 청능재활은 듣기, 말-언어, 화용(pragmatics), 인지(cognition) 등의 다양한 영역의 발달을 촉진하며, 원활한 구어 의사소통 발달이 가능하도록 장기간에 걸쳐서 진행된다. 임상 현장에서 전문가는 청능재활의 효과를 높이기 위해서 개 별화된 치료(individualized therapy) 외에도 부모를 대상으로 면담 및 상담, 강연회, 소그룹 내 시연 등의 다양한 방법으로 교 육을 진행하며, 가정에서도 부모가 자녀의 듣기, 말-언어 발달 을 촉진하고 치료실에서 배운 기술을 일반화(generalization)하 는 데 도움을 주고자 관련 자료를 제공하기도 한다. 선행 연구 (Barker, 2003; Fu \& Galvin, 2007; Nakeva von Mentzer et al., 2014)에서는 청각장애 아동의 말-언어, 읽기 발달에 도움이 되는 컴퓨터용 소프트웨어를 개발하여 중재를 진행하였으며, 중재 결과에서 컴퓨터를 이용한 중재(computer assisted intervention)가 보청기나 인공와우를 착용한 청각장애 아동의 단어, 음운인식, 명료도, 읽기 능력의 향상에 도움이 되는 것으 로 나타났다. 이렇듯 임상 현장과 연구 분야에서는 다양한 매 체, 방법, 자료를 활용하여 청능재활의 효과를 높이고자 하는 노력을 기울이고 있다.

컴퓨터를 이용한 중재는 장비와 소프트웨어의 높은 구입 비 용으로 인해 청능재활에 광범위하게 확산되기가 어려웠으나, 최근에는 모바일 기기(예: 스마트폰, 태블릿 PC 등)의 높은 보 급률과 어플리케이션(application, 앱)의 낮은 구입 비용으로 장애인의 교육과 재활에 모바일 러닝(mobile learning)을 적용 하고자 하는 움직임이 활발해지고 있다(Lee, 2016; Lee et al., 2015). Lim \& Park(2012)은 모바일 기기가 장소와 시간에 상관 없이 프로그램 접근이 쉬운 장점 외에도 컴퓨터에 비해서 작아 서 휴대하기 간편하고, 모바일 서비스(예: 음성 및 웹 서비스, 어 플리케이션 활용 등)를 활용할 수 있는 장점이 있다고 하였다. 국내에서는 Yu et al.(2014)이 청능재활 콘텐츠를 스마트폰 앱 으로 구현하여 청각장애 성인 $(\mathrm{n}=1)$ 에게 청능재활을 실시하였 으며, 청각장애 성인의 자음, 모음, 문장 수준의 어음인지력에 향상된 결과를 보고하였다. 현재는 모바일 러닝이 청능재활에 활용될 수 있는지에 대한 가능성을 탐색하는 단계라서 모바일
을 이용한 청능재활 효과를 보고한 사례가 미비한 상태이다. 하지만, 모바일 기기는 청능재활 콘텐츠를 그림, 글자, 음성, 동 영상, 애니메이션 등으로 구현이 가능한 장점을 지니고 있기 때 문에, 청능재활에서 청각장애 아동과 성인의 흥미를 유발하고 활동에 몰입하는 데 도움을 주어 효과적인 청능재활 도구가 될 수 있을 것이다(Lee, 2016).

$\mathrm{ASHA}$ (2017)에서는 청능재활의 궁극적인 목적이 청력손실 로 인해 발생되는 불이익을 최소화하여 청각장애인이 일상생 활에서 의사소통을 원활하도록 하는 것이라고 언급하였다. Cole \& Flexer(2011)는 인공와우 아동의 청능재활은 청각정보 에 대한 통합적인 듣기 발달을 강조해야 하며, 이를 토대로 구 어 의사소통에 필요한 말-언어 능력을 발달시키는 것이 목적이 라고 하였다. 듣기 기술은 언어적 의미를 지닌 음향학적 말소리 를 감지(detection), 변별(discrimination), 확인(identification) 하는 것에만 그치지 않고, 대화 상대자의 연결발화(connected speech)를 이해하여 대화, 토론, 학습까지 할 수 있는 광범위한 능력을 의미한다(Cole \& Flexer, 2011; Sweetow \& Sabes, 2006). 높은 수준의 듣기 기술을 발달시키기 위해서는 다양한 수준의 언어 단위(예: 음절, 단어, 문장)의 청각 자극을 듣고 차 례대로 회상할 수 있는 청각기억(auditory memory)의 발달이 필요하다(Sweetow \& Sabes, 2006). Spencer \& Delk(1989)는 고도 이상의 청각장애 아동은 구어 및 비구어 과제에서 모두 순차적으로 기억하는 항목의 개수가 정상청력 아동에 비해서 적다고 하였으며, 청각장애 아동의 기억용량과 읽기 기술과 관 련이 있다고 언급하였다. Jutras \& Gagné(1999)는 학령기 청각 장애 아동의 청각순서화 능력이 정상청력 아동에 비해서 낮다 고 보고하면서, 낮은 청각기억 능력은 청각정보처리 능력의 결 함(auditory processing deficits)과 관련이 있다고 하였다. Jang (2012)은 정상적인 말-언어 발달을 하고 있는 인공와우 아동 은 정상청력 아동과 동일하게 단어와 의미 간의 지식을 활용 하여 청각기억을 유지할 수 있었다고 언급하였으며, 높은 수준 의 듣기 기술과 의사소통 능력을 성취하기 위해서는 청각장애 아동을 위한 청능재활 프로그램에 청각기억에 초점을 맞춘 세 부 활동을 계획하여 진행하는 것이 필요하다고 강조하였다. 또 한 Wood(2013)는 청각장애 아동의 청각기억 발달 특성에 관한 연구가 미비한 것에 대해서 지적하면서, 청각장애 아동의 청각 기억 발달을 뇌 가소성(brain neuroplasticity)의 측면에서 연구 를 확장해 나갈 필요가 있다고 하였다. 이러한 관점을 토대로 볼 때, 청각기억을 촉진하는 청능재활은 궁극적으로 청각신경 시스 템 발달의 성숙에 중요하며, 청능재활 전문가는 청각단서(auditory only)만으로 진행되는 청각기억 활동을 통해 청각장애 아 동의 전반적인 청각정보의 이해(comprehension), 조작(manipulation), 회상(recall)의 통합적 발달을 촉진해야 할 것이다. 
인공와우 아동의 부모는 자녀와 가정에서 상호작용을 하고, 아동이 습득해야 하는 듣기, 말-언어를 촉진하는 데 어려움을 느낀다. 인공와우 아동의 의사소통 능력이 정상청력 아동에 비 해서 낮은 경우, 아동이 부모의 의사소통 시도에 부적절한 반 응을 보이거나 반응을 보이지 않기도 하며, 부모도 인공와우 아동이 이해하기에 어려운 방식으로 의사소통을 진행하기도 한다. 의사소통에 어려움을 지니는 아동의 발달에는 부모의 반 응이 매우 중요하기 때문에, 부모가 아동과 적극적으로 상호작 용하고 가정 내에서 중재하는 방법에 대해서 배우는 것이 필 요하다(Cheon \& Yim, 2016). 인공와우 아동의 부모를 대상으 로 한 부모교육과 관련된 선행 연구(Lee, 2008b; Lee \& Seok, 2006)에서는 부모교육을 통해서 가정에서 부모와 인공와우 아 동 간의 상호작용 빈도뿐만 아니라 인공와우 아동의 상호작용 능력도 향상되었다고 보고하였다. 청능재활 전문가의 직접적인 중재 외에도 가정에서 부모가 인공와우 아동의 청각기억을 향 상시키기 위해서 부모에 의한 가정 중재가 진행된다면, 청각기 억 중재에 대한 일반화 효과로 더 나은 수행력 증가를 기대할 수 있을 것이다.

임상 현장에서 청각장애 아동은 구조화된 상황에서 제공되 는 청각기억 향상을 위한 반복적인 활동과 자료에 피로감과 지 루함을 느끼기도 한다. 그러므로, 청각장애인이 흥미를 가지고 참여할 수 있는 다양한 청능재활 도구를 개발하는 것은 중요 하며(Baek \& Lee, 2016), 스마트 시대로 인해 모바일 러닝에 대 한 관심이 높아지는 시점에서 청각장애 아동의 청각기억 향상 을 위해서 개발한 콘텐츠를 앱으로 구현하여 중재 효과를 살펴 보는 것은 의의가 있겠다. 본 연구에서는 스마트폰 앱을 이용한 청능재활을 인공와우 아동에게 실시하여 인공와우 아동의 청 각기억 향상에 미치는 영향을 알아보고자 하였으며, 부모의 앱 을 이용한 청능재활에 대한 만족도에 대해서도 살펴보고자 하 였다. 이를 위한 구체적인 연구 질문은 다음과 같다.

첫째, 앱을 이용한 중재 동안 인공와우 아동의 회기별 청각 기억 점수는 어떠한가?

둘째, 앱을 이용한 중재 전후에 따라 인공와우 아동의 청각 기억 점수에 유의한 차이가 있는가?

셋째, 앱을 이용한 중재에 대한 인공와우 아동의 부모의 교 육 효과와 만족도는 어떠한가?

\section{MATERIALS AND METHODS}

\section{연구 대상}

본 연구는 부산에 거주하는 인공와우 아동 3 명을 대상으로 하였다. 대상자를 선정한 구체적인기준으로는 1) 선천성 농 (congenital deaf)이며, 2) 3세 이전에 첫번째 인공와우이식을
받고, 3) 지적장애, 자폐스펙트럼장애 등과 같은 중복장애(multiple disabilities)가 없으며, 4) 구어 의사소통이 가능하고, 5) 통 합교육 환경에 배치되어 있으며, 6) 부모 보고에 의해 스마트폰 의 조작에 어려움이 없다고 한 아동만을 대상으로 선정하였다. 연구에 참여한 대상 아동의 정보는 Table 1에 제시하였다.

\section{인공와우 아동 $A$ 의 배경정보}

아동 $\mathrm{A}$ 는 중재 당시 39 개월로, 2 세 11 개월에 좌측에 인공와 우이식을 받고 술 후부터 청각구어법(auditory verbal appro$\mathrm{ach}$ )의 청능재활을 주 2 회 받고 있다. 수용 및 표현어휘력 검사 (Receptive and Expressive Vocabulary Test, REVT) (Kim et al., 2009)에서 수용점수는 15점, 표현점수는 20점이었다. REVT 검사 결과 수용과 표현 언어에서 언어발달 연령이 30개 월 미만으로 언어발달지체를 보이고 있었다. 아동용 발음평가 (Assessment of Articulation and Phonology for Children, $\mathrm{APAC}$ ) (Kim et al., 2007)에서 자음정확도가 50.0\%, 백분위수 $1 \%$ ile 미만으로 말소리장애(speech sound disorders)로 진단되 었다. 보기가 없는 조건의 단음절단어검사(Lee et al., 2009)에 서 단어수준은 $70 \%$, 음소수준은 $74 \%$ 였다. 부모 보고에 의하 면, 본 아동은 어휘 표현에 어려움이 있으며, 말 산출시 음도 (pitch)가 높고 말속도가 빠르며, 말명료도(speech intelligibility)가 낮아서 친숙하지 않은 사람과는 의사소통이 어렵다고 하 였다.

\section{인공와우 아동 $\mathrm{B}$ 의 배경정보}

아동 $\mathrm{B}$ 는 중재 당시 97 개월로, 1 세 4 개월에 우측에 첫 번째 인공와우이식을 받았으며, 7세 9개월에는 좌측에 두 번째 인공 와우이식을 받았다. 중재 당시, 양측에 인공와우를 착용하고

Table 1. Characteristics of three children with cochlear implants

\begin{tabular}{lccc}
\hline \multicolumn{1}{c}{ Characteristics } & Child A & Child B & Child C \\
\hline Chronological age (months) & 39 & 97 & 75 \\
Sex & $\mathrm{M}$ & $\mathrm{M}$ & $\mathrm{M}$ \\
Age at fitting hearing aids (months) & 3 & 4 & 12 \\
Age at the first implantation (months) & 35 & 16 & 31 \\
Duration of an implant use (months) & 4 & 81 & 44 \\
Phoneme score of the MW test (\%) & 74 & 74.6 & 83.1 \\
PCC (\%) & 50.0 & 44.3 & 41.1 \\
REVT-R (score) & 15 & 44 & 16 \\
REVT-E (score) & 20 & 32 & 10 \\
\hline
\end{tabular}

Adapted from Korean Journal of Otorhinolaryngology-Head and Neck Surgery (Lee et al., 2009). Adapted from Community Rehabilitation Center (Kim et al., 2009). M: male, MW: monosyllabic word (Lee et al., 2009), PCC: Percentage of Consonants Correct, REVT-R: Receptive \& Expressive Vocabulary Test-Receptive (Kim et al., 2009), REVT-E: Receptive \& Expressive Vocabulary TestExpressive (Kim et al., 2009) 
청각구어법의 청능재활을 주 2회 받고 있었다. REVT (Kim et al., 2007)에서 수용점수는 44점, 표현점수는 32점으로 평가되 었으며, 언어발달 연령은 수용언어는 44개월, 표현언어는 30 개 월 수준으로 나타나서 언어발달장애를 보이고 있었다. APAC (Kim et al., 2007)에서 자음정확도가 44.3\%, 백분위점수가 $1 \%$ ile 미만을 보여서 말소리장애였다. 보기가 없는 조건의 단음 절단어검사(Lee et al., 2009) 결과, 단어수준은 $46 \%$, 음소수준 은 $74.6 \%$ 였다. 본 아동은 일반 초등학교 통합학급에 배치되어 있으며, 의사소통과 학습의 어려움으로 보조 선생님의 도움을 받아서 수업에 참여하고 있다. 부모의 보고에 따르면, 말 산출 시 음도가 높고, 말명료도도 낮아서 또래와의 의사소통에 어려 움이 있다고 하였다.

\section{인공와우 아동 $\mathrm{C}$ 의 배경정보}

아동 $\mathrm{C}$ 는 중재 당시 75 개월로, 1 세 6 개월에 우측에 인공와우 이식을 받았으나 내부 기기의 결함(device failure)으로 2세 7개 월에 같은 측에 인공와우이식을 다시 받았다. 본 아동은 첫 번 째 인공와우이식 후부터 지속적으로 청각구어법의 청능재활을 주 2회 받고 있다. REVT (Kim et al., 2009)에서 수용점수는 16점, 표현점수는 10 점이었으며, 언어발달 연령이 두 영역에서 모두 30개월 미만이어서 언어발달장애를 보이고 있었다. APAC (Kim et al., 2007)에서 자음정확도 $41.1 \%$, 백분위수 $1 \%$ ile 미 만으로 말소리장애를 보이고 있었다. 보기가 없는 조건의 단음 절단어검사(Lee et al., 2009) 결과, 단어수준은 68\%, 음소수준

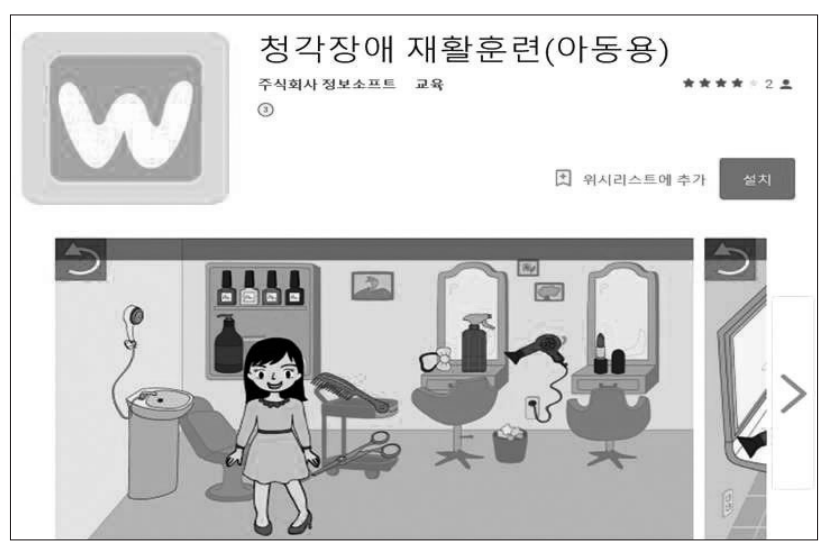

Figure 1. Applications used in this study. Adapted from Lee. Audiology and Speech Research 2017;13(1):50-61, with permission of Audiology and Speech Research.
은 83.1\%였다. 부모 보고에 따르면, 본 아동은 조사를 생략하 는 전보식(telegraphic) 형태의 문장으로 대화를 하며, 낮은 말 명료도로 어린이집 선생님과 또래와의 의사소통이 원활하지 않다고 한다.

\section{연구 도구}

본 연구에서는 구글플레이(Google play)에 '청각장애 재활훈 련(아동용)'으로 등록되어 있는 앱으로 중재를 실시하였으며 (Figure 1), 연구자는 중재를 위해서 안드로이드 기반의 스마트 폰(LG Optimus G2, F302; LG Electronics, Pyeongtaek, Korea)에 앱을 설치하였다(Lee, 2017). 본 연구에서 사용한 앱의 콘텐츠는 청능재활 전문가의 임상경험과 지식을 토대로 개발되 었으며, 앱의 에피소드는 청각장애 아동의 흥미를 유발할 수 있도록 일상생활의 직간접적인 경험을 반영하였다. 본 앱에서 사용할 어휘에 대한 점검은 친숙도와 교육 적절성의 두 가지 측 면으로 진행되었다. 어휘의 친숙도는 유치원 교사에 의해서 정 상적인 말-언어 발달을 하고 있다고 보고된 취학 전의 정상청 력 아동을 자녀로 두고 있는 어머니 3명에게 진행하였으며, 해 당 어휘에 대해서 5점 Likert 척도(1점: 매우 친숙하지 않음, 2 점: 친숙하지 않음, 3점: 보통, 4점: 친숙함, 5점: 매우 친숙함)로 평정하게 하였다. 어휘의 언어치료 적절성은 임상경력이 5년 이 상인 언어치료사 3 명에게 어휘가 교육용으로 적절한지에 대해 5점 Likert 척도(1점: 매우 적절하지 않음, 2점: 적절하지 않음, 3점: 보통, 4점: 적절함, 5점: 매우 적절함)를 이용하여 평정하도 록 하였다. 이 과정을 통해서 어머니와 언어치료사에게 친숙도 와 교육 적절성 모두 4점 이상으로 평정된 어휘만을 어휘 목록 에 포함시켰으며, 해당 어휘 중에서 앱 시나리오에 적절한 것만 을 선정하여 사용하였다. 앱은 취학 전 아동의 언어발달 수준 을 고려하여 문자 없이 진행되도록 설계되었으며, 간단한 프레 임(듣기-기억하기-선택하기-확인하기)으로 앱을 구현하여 청 각장애 아동도 짧은 시간 안에 쉽게 앱을 독립적으로 사용할 수 있다.

중재에 사용한 앱은 총 6 개의 에피소드로 구성되어 있으며, 각 에피소드에는 난이도가 세 단계로 구분되어 있다. 난이도는 아동이 기억해야 하는 중심어(key word)의 개수(예: 사과, 귤수박, 사과-딸기-키위)에 따라서 $1,2,3$ 단계로 구분된다. 아동 이 참여한 에피소드의 청각기억 점수가 $80 \%$ 이상으로 연속 3

Figure 2. Examples of the application's screen. Adapted from Lee (2017). Audiology and Speech Research, 13(1), 5061, with permission of Audiology and Speech Research.
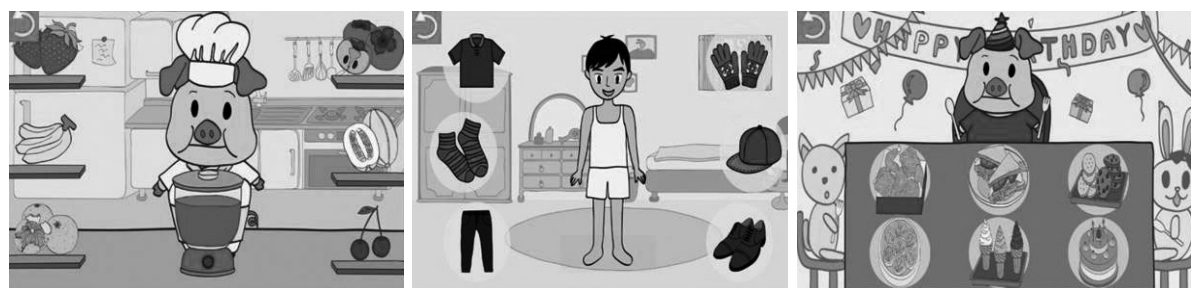

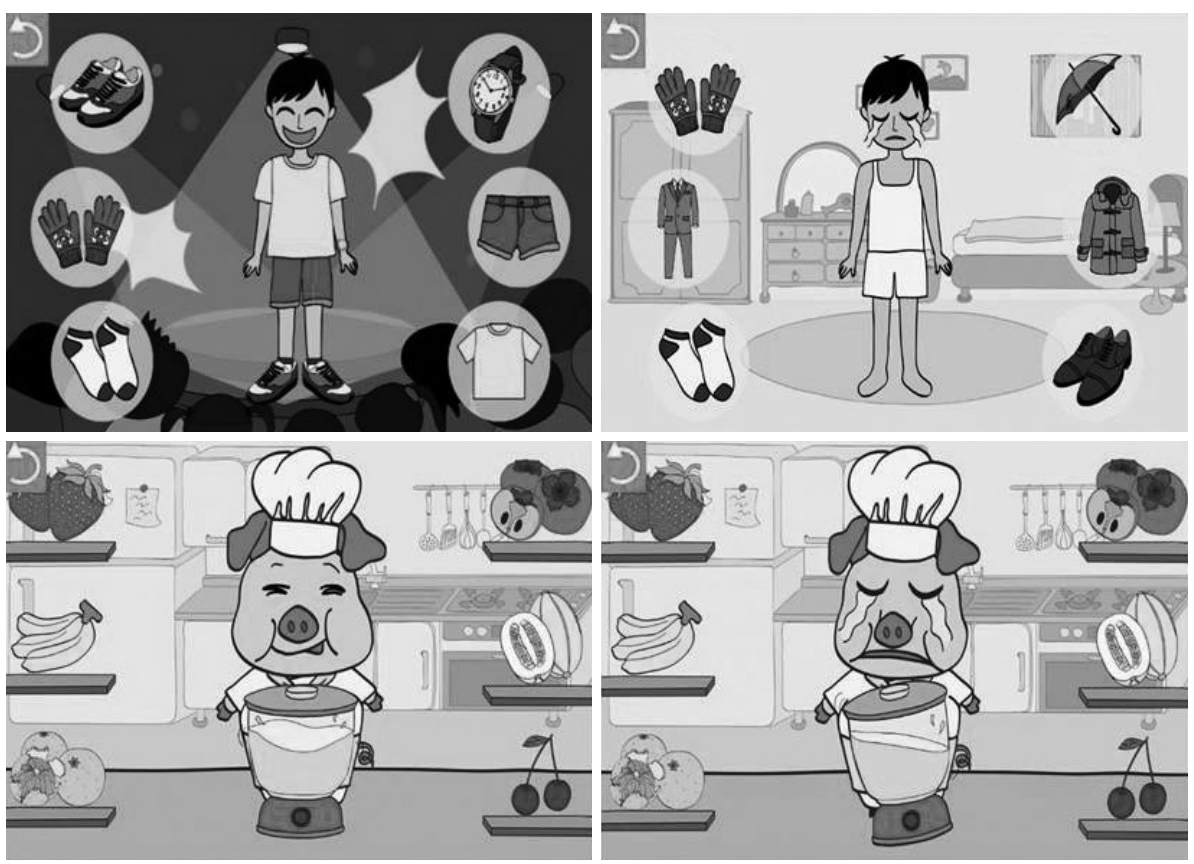

Figure 3. Examples of correct and incorrect feedback.

회 이상 수행하였을 때에 자동적으로 난이도가 다음으로 이동 된다. 중재에 사용된 앱에서는 아동이 흥미를 가지고 집중력 있게 활동에 참여할 수 있도록 보기가 있는 조건(closed-set condition)에서 청각기억을 할 수 있도록 계획하였으며, Figure 2 와 같은 화면이 스마트폰에 제시된다. 아동은 에피소드에 따 라 제시되는 6 개의 단어 이미지를 먼저 본 후에 청각단서만으 로 제시되는 목표 단어를 듣고 해당되는 이미지를 순차적으로 선택(예: 터치, 드래그)하며, 아동은 정오반응에 대한 피드백을 캐릭터의 애니메이션과 효과음으로 받을 수 있다. 이때, 단어 이미지는 랜덤방식으로 제시되도록 프로그래밍이 되어 있어서, 아동이 다양한 단어와 이미지로 청각기억 중재 활동에 참여할 수 있다. 정반응의 피드백은 제시된 단어와 그 순서가 아동의 반응과 일치한 경우에, 오반응의 피드백은 제시된 단어와 그 순서가 일치하지 않거나 5초 이상 반응이 없는 경우에 적절히 제공되도록 프로그래밍되었다(Figure 3).

\section{연구 절차}

본 연구는 부산 소재의 청능재활 기관에서 2016년 3월 28일 부터 5월 9일까지 진행되었다. 연구 절차는 앱 중재에 대한 부 모 오리엔테이션, 청각기억의 사전-사후 평가, 앱 중재, 부모 만 족도 평가로 이루어졌다. 연구자는 중재와 사전-사후 평가 과 정을 디지털캠코더(HDR-SR7; Sony Corporation, Tokyo, Ja$\mathrm{pan)}$ 로 촬영하였다. 연구절차의 각 과정에 대한 구체적인 내용 은 다음과 같다.

\section{부모 오리엔테이션}

인공와우 아동의 부모에게 앱 중재에 대한 이해를 돕고자 개 별적으로 연구 목적을 설명하고 앱에 대해서 설명하는 시간을 가졌으며, 중재 연구에 자발적으로 참여하기를 희망한다는 의 사를 전달받고 연구참여동의서에 서명을 받았다. 연구자는 스 마트폰의 앱에 로그인, 에피소드 선택, 청각기억 활동 진행, 점 수 이력 확인 등 앱을 활용하는 방법을 부모에게 설명하고 충 분히 숙지할 수 있도록 시연을 하였다. 그리고 연구자는 가정에 서 앱을 사용하여 자녀와 상호작용할 수 있는 방안과 아이디어 에 대해서 부모와 이야기를 나누었다.

\section{사전-사후 평가}

청각기억 과제는 $\operatorname{Jang}(2012)$ 의 의미 단기기억검사를 수정, 보 완하여 사용하였다. 본 연구에서는 단어길이효과(word length effect)가 대상 아동의 말지각에 미치는 영향을 고려하여 사 전-사후 평가 문항을 1 3음절 단어로 균형화하였으며(Baddeley, 2003), 단어 친숙도가 아동의 말지각에 미치는 영향을 최 소화하기 위해서 문항의 단어의 친숙도에 대한 타당도 점검을 청능재활 전문가 1 인에게 실시하였다. 평가에 사용될 단어가 청각장애 아동에게 친숙한지에 대해서 청능재활 경험이 5년 이 상인 전문가에게 5점 Likert 척도(1점: 매우 친숙하지 않음, 2 점: 친숙하지 않음, 3점: 보통, 4점: 친숙함, 5점: 매우 친숙함)를 이용하여 평정하게 하였으며, 4점 이상으로 평정되지 않은 단 어는 전문가와 상의하여 단어를 수정하였다. 본 연구에서 사용 한 사전-사후검사는 Jang(2012)의 검사에서 구분된 의미 범주 
목록(categorical items)과 비범주 목록(non-categorical items) 의 틀을 그대로 유지하되, 각 목록의 문항을 5 개씩 구성하고, 각 문항에는 5 개의 단어로 구성하였다. 여기서 범주 목록(예, 과일, 탈것 등)의 문항에는 의미적으로 공통적 속성이 많은 단 어만으로 구성하였으며, 비범주 목록에는 의미적으로 공통적 속성이 없거나 매우 적은 단어만으로 구성하였다. 사전-사후 평 가에서 사용한 청각기억 검사는 Appendix 1에 제시하였다.

사전-사후 평가에서 외부와 내부의 소음을 최대한 통제하기 위해서 청능재활기관 내 가장 조용한 공간에서 대상 아동에게 개별적으로 진행하였다. 연구자는 연습문항을 통해서 아동에 게 5 개의 단어를 듣고 나서 들은 순서대로 단어를 회상해서 말 해야 한다는 것을 숙지시켰다. 본 검사에서 연구자는 보기가 없는 조건에서 문항 내 5 개의 단어를 청각 단서만으로 아동에 게 1초 간격으로 들려주었으며, 아동이 단어를 들은 순서대로 회상(serial recall)하여 말하도록 하였다.

\section{중재 프로토콜}

연구자는 중재를 치료실 내 독립된 공간에서 아동과 나란히 앉아서 진행하였으며, 중재 과정을 캠코더(HDR-SR7, SONY)로 촬영하였다. 연구자의 직접 중재는 총 5 주 동안, 매주 1 회씩, 15 20분 동안 진행되었다. 중재 동안, 연구자는 부모가 가정에 서 진행한 앱 중재에 대한 피드백을 부모교육을 통해서 제공하 였다. 본 연구에서 언어재활사 2급 자격증 소지하고 언어병리학 석사를 수료한 연구자 1 명이 중재를 진행하였으며, 중재를 실시 하기 전부터 학사와 석사 과정에서 청능재활과 관련된 교과목 이수와 청능재활 임상경험을 통해서 청각구어법 등의 재활 접

Introduction

- Greeting with the child

- Having the daily conversation for 5 minutes

- Explaining about the intervention for child

\section{$\downarrow$}

Demonstration

- Practicing with the frame of 'listening-remembering-selecting' - Repeating until the child understands the rule of how the application is manipulating and participating

\section{$\Downarrow$}

Intervention

- Login the application on the smartphone

- Selecting the application's episodes

- Participating in the intervention

- Identifying the results

- Parental education

Figure 4. Protocol of intervention used in the present study.
근법을 숙지한 상태에서 중재를 진행하였다. 중재 프로토콜은 Figure 4에 제시하였다.

중재는 회기마다 도입, 시연, 중재의 단계로 진행하였다. 도입 단계에서 연구자는 아동과 인사를 나눈 후, 착석하여 5 분간 간 단한 일상 대화를 나눴다. 연구자는 아동에게 앱을 활용하는 모습을 보여주면서 중재 과정에 대해 설명하였다. 시연 단계에 서는 '듣기-기억하기-선택하기'의 프레임으로 연습을 진행하여 아동이 앱의 기능과 연습방법을 충분히 습득할 수 있도록 하였 다. 도입과 시연 단계에서 아동이 앱 조작과 참여방법을 충분히 이해할 때까지 반복하였으며, 아동이 완벽하게 숙지했다고 판 단된 후에 중재를 시작하였다.

중재 단계에서는 스마트폰에서 앱 로그인하기, 에피소드 선 택하기, 앱 중재에 참여하기, 결과 보기, 부모교육으로 진행되었 다. 연구자는 아동이 스마트폰을 편하게 조작할 수 있도록 스마 트폰과 아동의 거리를 조절하였으며, 로그인하여 아동이 선호 하는 에피소드의 아이콘을 직접 선택하도록 했다. 중재 동안, 아동의 미숙한 조작으로 앱이 중단되었을 경우에 다시 활동에 참여하도록 유도하였다. 연구자는 아동에게 정답을 요구하거나 확인하려 하지 않았으며, 아동 스스로 앱 활동에 참여하도록 유도하였다. 하지만, 아동이 잘못 수행했을 경우에는 잠시 활동 을 중단하고, 적절한 피드백을 제공하여 아동이 정확하게 앱 진행 규칙을 알 수 있도록 하였다. 예를 들면, 아동이 2 개의 중 심단어를 선택하도록 요구하는 2 단계 난이도에서 1 개의 단어 이미지만 선택하는 것과 같이, 아동이 앱 진행 규칙 이해에 혼 동이 왔을 경우에 연구자는 ‘두 개를 들었어요. 두 개를 고르세 요.라고 말하였다. 외부 소음 등으로 아동이 음성을 듣지 못하 여 반복청취를 요구하였을 때에는 연구자가 목표 단어를 다시 들려주고 선택하도록 하였다. 에피소드 활동이 종료되면, 아동 의 앱 수행 결과를 바로 확인할 수 있었기 때문에, 연구자는 아 동에게 결과를 보여주면서 칭찬과 격려를 하였다.

부모교육은 매 중재 회기를 마친 후에 약 10 분 동안 진행하 였다. 연구자는 앱에 저장된 아동의 청각기억 수행력, 아동의 태도 및 반응에 대한 정보를 부모에게 제공하였다. 그리고 부모 가 가정에서 아동과 상호작용을 하면서 앱을 활용할 수 있는 방법에 대해서 설명하고, 부모가 관찰한 아동의 반응과 학습 이력을 확인하였다. 이때, 연구자는 부모가 아동에게 적절하지 않은 방법으로 제공하는 상호작용 기술에 대한 개선 방안에 대해 함께 이야기를 나누었다.

\section{앱 중재에 대한 부모의 교육 효과와 만족도에 대한 평가}

본 연구에서는 설문을 통해서 인공와우 아동의 부모가 앱 중재에 대한 만족도를 평가하였다. 설문 문항은 선행 연구(Jang \& Song, 2015; Kim et al., 2014; Lee et al., 2014)를 참조로 하 
여, 교육 효과성(11문항)과 교육 만족도(11문항)의 22문항으로 개발하였다. 설문의 세부 내용을 살펴보면, 교육 효과성에서는 교육 목표의 명확성, 교육적 가치, 적절성, 위계성, 어휘의 적절 성, 활동의 다양성, 유희성, 경험과의 연결 등의 문항으로 구성 되어 있으며, 교육 만족도에서는 학습 내용의 전달 정확성, 학 습 동기의 유도, 학습의 만족감 등의 문항으로 구성되었다. 각 문항에 대한 반응은 5점 Likert 척도를 통해 1점에서 5점까지(1 점: 전혀 그렇지 않다, 2점: 그렇지 않다, 3점: 보통이다, 4점: 그 렇다, 5점: 매우 그렇다)로 제시하여 응답할 수 있도록 하였다. 앱 중재에 대한 부모 만족도 평가에 관한 설문 문항은 Appen$\operatorname{dix} 2$ 에 제시하였다.

\section{자료 분석}

앱을 이용한 중재 효과를 살펴보기 위해서, 중재 동안 앱 활 동 결과로 회기별 청각기억 점수를 산출하였으며, 중재 전과 후 에 청각기억 점수를 산출하였다. 중재 동안 회기별 청각기억 점 수는 문항별로 정반응 1점, 오반응 0점으로 자동적으로 채점, 저장되는 앱의 기능을 활용하여, 매주 청각기억 점수를 0 $100 \%$ 의 정확도로 산출하였다. 사전-사후 검사의 청각기억 채점 은 Jang(2012)이 제시한 청각기억의 채점 기준에 따라서 연구자 에 의해서 진행하였다. 연구자는 청각기억 사전-사후검사가 진 행되는 동안 아동의 반응을 기록지에 모두 기록하였으며, 아동 의 반응이 연구자가 들려준 문항의 단어와 순서가 모두 일치하 면 정반응(1점), 단어와 순서가 일치하지 않으면 오반응(0점)으 로 채점하였다. 사전-사후 평가에서 청각기억 점수는 목록(범 주 목록, 비범주 목록)에 따라 채점하였으며, 각 범주에 따라 $0 \sim 100 \%$ 의 정확도(\%)로 산출하였다.

\section{신뢰도 및 중재 충실도}

본 연구에서 분석한 자료에 대한 신뢰도는 검사자 내 신뢰도 (inter-rater reliability)를 통해서 산출하였다. 신뢰도 산출을 위해서 중재에 참여한 인공와우 아동 3명의 평가 동영상 자료 를 재분석하여 일치도(agreement)를 분석한 결과, 대상 아동의 점수 신뢰도는 모두 $100 \%$ 로 나타났다.

중재가 계획된 대로 잘 실행되었는지를 확인하기 위해서 중재 충실도를 평가하였다. 중재 충실도 문항은 Park \& Yim(2015)의 연구에서 사용된 체크리스트를 참고로 하여 본 연구 목적에 맞 도록 수정, 보완하였다. 본 연구에서 사용한 중재 충실도 체크 리스트는 중재 계획(2문항), 중재 실행(6문항), 중재 평가(2문항) 에 대해서 묻는 총 10 개의 문항으로 구성되어 있다. 영역별로 살펴보면, 중재 계획에는 일정과 내용 구성에 관한 문항이, 중재 실행에는 부모 오리엔테이션을 통한 연구 목적 및 앱에 관한 설 명, 중재 전략 방법에 관한 문항이, 중재 평가에는 중재 일반화
에 관한 문항이 포함되어 있다. 연구자는 매 회기마다 자기 평 가 방식으로 중재 충실도 문항에 '예(1점)-아니오(0점)’로 응답 하였다. 중재 충실도의 점수는 세 개의 영역별로 따로 산출하 여, 해당 영역의 점수를 총점으로 나누어서 100 을 곱하여 0 100 점으로 산출하였다. 그 결과, 진행한 회기에서 중재 계획, 중 재 실행, 중재 평가 영역에서 모두 100점이었다. 본 연구에서 사 용된 중재 충실도의 체크리스트는 Appendix 3에 제시하였다.

\section{실험 설계}

본 연구에서는 사전-사후 비교 설계(pretest-posttest de$\operatorname{sign)}$ 를 사용하여, 사전 평가, 중재, 사후 평가 단계로 구성하였 다. 사전 평가 단계에서는 대상자의 적절성 판단, 부모에게 중재 에 대한 설명 및 동의를 얻은 다음에 청각기억에 대한 사전평 가를 실시하였다. 중재 단계에서는 청능재활 전문기관 내 언어 치료실에서 연구자가 대상 아동에게 개별적으로 앱 중재를 진 행하였다. 이때, 회기별 앱을 통해서 자동적으로 저장되는 청각 기억 평가 결과를 수집하였다. 사후 평가 단계에서는 청각기억 검사를 중재 종료 후 일주일 안에 실시하였으며, 사전 평가와 동일한 절차로 진행하였다.

\section{통계 분석}

앱을 활용한 중재 전후의 청각기억 점수에 유의한 차이가 있 는지를 살펴보기 위해서 비모수 통계 방법인 윌콕슨 부호순위 검정(Wilcoxon signed-ranks test)을 실시하였으며, 중재 동안 의 회기별 청각기억 점수와 앱 중재에 대한 부모의 교육 효과 와 만족도에 대해서는 기술통계를 실시하였다. 본 연구의 자료 분석은 IBM SPSS Statistics version 22 (IBM Co., Armonk, NY, USA)를 사용하였다.

\section{RESULTS}

\section{인공와우 아동의 청각기억 중재 효과}

앱을 이용한 중재가 인공와우 아동의 청각기억에 미치는 영 향을 살펴보기 위해서, 중재 동안 인공와우 아동의 회기별 청

Table 2. Descriptive statistics results from auditory memory accuracy $(\%)$ weekly evaluated by the smartphone application for children with cochlear implants $(n=3)$

\begin{tabular}{lcccc}
\hline & Child A & Child B & Child C & Mean (SD) \\
\hline Session 1 & 6.7 & 26.7 & 33.3 & $22.2(13.9)$ \\
Session 2 & 11.1 & 60.0 & 88.9 & $53.3(39.3)$ \\
Session 3 & 15.5 & 68.9 & 86.7 & $57.0(37.1)$ \\
Session 4 & 28.9 & 60.0 & 97.6 & $65.1(34.4)$ \\
Session 5 & 26.7 & 82.2 & 86.7 & $56.5(33.4)$ \\
\hline
\end{tabular}

SD: standard deviation 

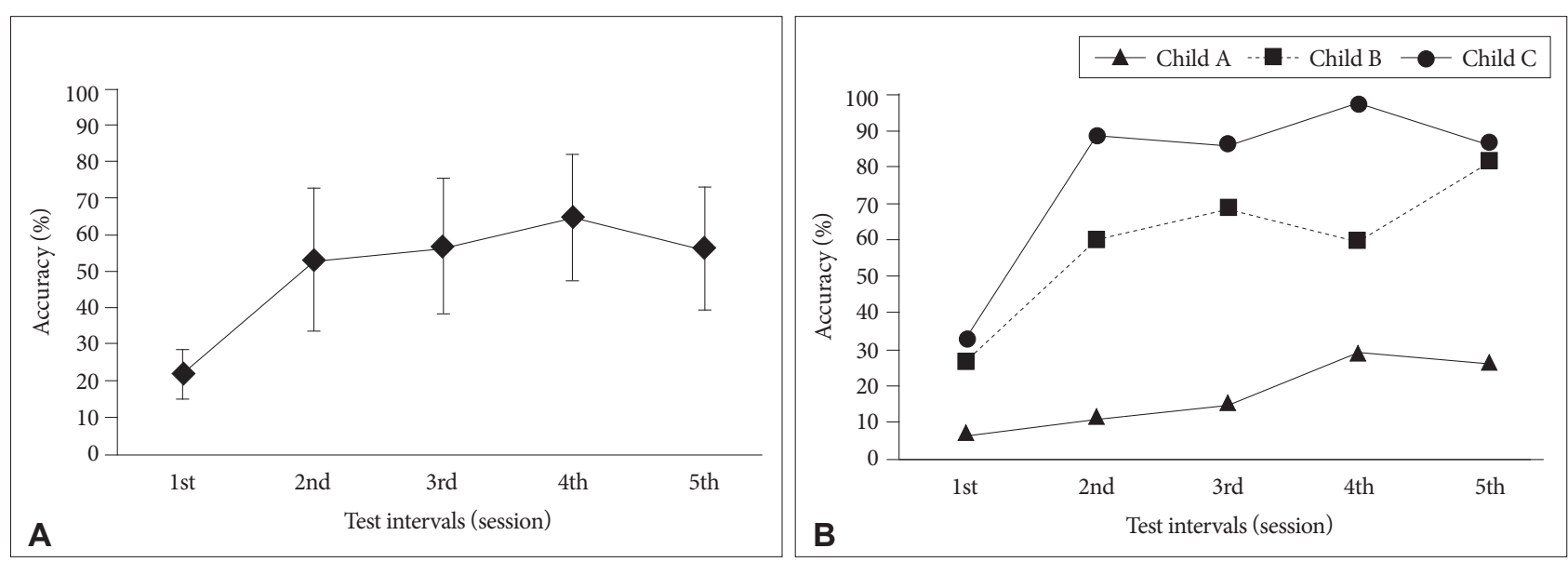

Figure 5. Auditory memory accuracy from the aural habilitation sessions. A: Mean accuracy of auditory memory for children with cochlear implants, B: Accuracy of auditory memory for three children with cochlear implants.

각기억 점수와 중재 전후의 청각기억 점수를 산출하였다.

중재 동안 아동이 참여한 앱에서 자동적으로 저장되는 청각 기억 점수에 대한 기술통계분석을 실시하였으며, 그 결과는 Table 2에 제시하였다. 대상 아동의 회기별 청각기억의 평균 점 수를 살펴보면, 22.2\%[standard deviation (SD) = 13.9], 53.3\% $(\mathrm{SD}=39.3), 57.0 \%(\mathrm{SD}=37.1), 65.1 \%(\mathrm{SD}=34.4), 56.5 \%(\mathrm{SD}=$ 33.4)로 나타났다. 아동 $\mathrm{A}$ 의 청각기억 점수는 6.7, 11.1, 15.5, 28.9, 26.7\%로, 마지막 회기의 점수가 첫 번째 회기에 비해서 약 $20 \%$ 향상되었다. 아동 $\mathrm{B}$ 의 청각기억 점수는 26.7, 60.0, 68.9, $60.0,82.2 \%$ 였으며, 청각기억 점수의 향상이 두 번째 회기부터 두드려져서 유지되는 경향을 보였다. 아동 $\mathrm{C}$ 의 청각기억 점수 는 33.3, 88.9, 86.7, 97.6, 86.7\%였으며, 두 번째 회기부터 청각기 억 점수의 향상이 두드러진 경향을 보였다(Figure 5).

중재 전후의 청각기억 점수에 유의한 차이가 있는지를 살펴 보기 위해서 윌콕슨 부호순위 검정(Wilcoxon signed-ranks test)을 실시하였다. 청각기억 검사의 범주 목록과 비범주 목록 의 청각기억 점수에 대한 기술통계 및 윌콕슨 부호순위 검정의 결과는 Table 3에 제시하였다. 범주와 비범주 목록을 합친 청각 기억 점수의 사전 점수가 $9.3 \%(\mathrm{SD}=9.24)$, 사후 점수가 $17.3 \%$ $(\mathrm{SD}=11.02)$ 로 나타나서, 중재 후의 청각기억 점수가 중재 전 에 비해서 유의하게 향상되었다 $(\mathrm{Z}=-2.214, p<0.05)$. 목록별 로 살펴보면, 범주 목록에서 청각기억의 사후 점수가 $26.7 \%(\mathrm{SD}$ $=25.40)$ 로, 사전 점수인 $12.0 \%(\mathrm{SD}=17.44)$ 보다 유의하게 높았 다 $(\mathrm{Z}=-2.214, p<0.05)$. 비범주 목록에서 청각기억의 사후 점 수는 8.0\%( $\mathrm{SD}=4.0)$ 로 사전 점수인 $6.7 \%(\mathrm{SD}=1.6)$ 에 비해 향 상되기는 하였으나, 청각기억 점수의 사전-사후에 대한 차이는 유의하지 않았다 $(\mathrm{Z}=-1.857, p>0.05)$ (Figure 6).

\section{중재에 대한 부모 평가}

본 연구에 참여한 인공와우 아동의 부모에게 앱을 이용한 중
Table 3. Pre-post comparisons of auditory memory accuracy on categorical and non-categorical items for children with cochlear implants $(n=3)$

\begin{tabular}{lcccc}
\hline \multicolumn{1}{c}{ Categorical type } & Accuracy (\%) & SD & $Z$ & $p$ \\
\hline Categorical items & & & $-2.214^{*}$ & 0.027 \\
$\quad$ Pre & 12.0 & 17.44 & & \\
Post & 26.7 & 25.40 & & \\
Non-categorical items & & & -1.857 & 0.063 \\
Pre & 6.7 & 1.6 & & \\
Post & 8.0 & 4.0 & & \\
\hline
\end{tabular}

${ }^{*} p<0.05$. SD: standard deviation

재에 대한 교육 효과와 만족도 평가를 실시한 결과는 Table 4 에 제시하였다. 교육 효과의 평균점수는 3.7점( $\mathrm{SD}=0.85)$, 교육 만족의 평균점수는 3.3점 $(\mathrm{SD}=0.98)$ 으로 나타나서, 인공와우 아동의 부모는 앱을 이용한 중재에 대해서 교육 효과성을 교육 만족도에 비해서 높게 평가하였다. 대상 아동별로 살펴보면, 아 동 $\mathrm{B}$ 와 $\mathrm{C}$ 의 부모가 아동 $\mathrm{A}$ 에 비해서 교육 효과와 만족도에서 높은 평가를 하였다(Figure 7).

\section{DISCUSSIONS}

청능재활 전문가는 청각장애 아동의 원활한 의사소통을 위 해서 청각장애 진단 후의 보청기 및 인공와우 착용과 함께 청 능재활이 중요하다는 것을 가족에게 강조하며, 청각장애 아동 은 장기간 동안 가족과 청능재활에 참여하여 듣기, 말-언어 능 력을 습득한다. 최근 들어, 청능재활 분야에서는 청각장애 아 동 및 성인의 재활 참여의 흥미와 몰입을 증가시켜 중재 효과 를 높이기 위한 콘텐츠와 도구 개발에 대한 방법을 모색하고 있다. 청각장애인의 어음인지 향상을 위한 가로세로판 개발 (Baek \& Lee, 2016), 스마트폰 어플리케이션 개발 및 중재(Yu et al., 2014) 등과 같은 다양한 청능재활 도구에 대한 사례가 

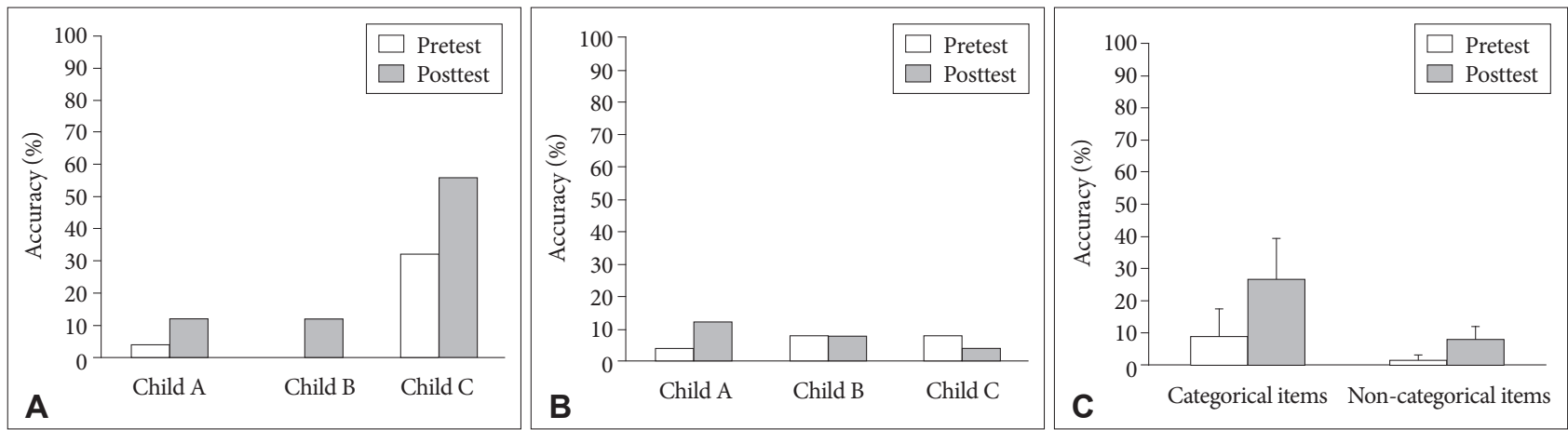

Figure 6. Pre-post comparisons of auditory memory accuracy from the aural habilitation using smartphone application. A: Accuracy of categorical items in each child with cochlear implants. B: Accuracy of non-categorical items in each child with cochlear implants. C: Accuracy of categorical and non-categorical items in three children with cochlear implants.

Table 4. Descriptive statistics results from mothers' perception of educational effectiveness and satisfaction about aural habilitation using the smartphone applications (five-point scale with a maximum score of 5)

\begin{tabular}{lcccc}
\hline & Child A's mother & Child B's mother & Child C's mother & Mean (SD) \\
\hline Educational effectiveness & 2.8 & 3.7 & 4.5 & $3.7(0.85)$ \\
Educational satisfaction & 2.3 & 3.5 & 4.2 & $3.3(0.98)$ \\
\hline
\end{tabular}

SD: standard deviation



보고되어, 청각장애인이 청능재활에서 느낄 수 있는 피로도 및 지루함이 감소되고, 어음인지력 향상에도 긍정적이라는 결과가 소개되었다. 이러한 시점에서 전문가들은 스마트폰이 광범위하 게 보급되어 사용되고 있는 현대 사회의 변화에 맞추어서 모바 일이 청각장애 아동의 교육과 재활 분야에서 학습 도구로 사용 될 수 있다는 점에 주목하고 있으며, 모바일 응용 프로그램인 앱이 장애인의 교육과 재활의 다변화에 영향을 미칠 것으로 예 측하고 있다(Jang \& Song, 2015; Lee et al., 2015; Lim \& Park, 2012). 이에 따라 본 연구에서는 스마트폰 앱을 이용한 중 재가 인공와우 아동의 청각기억에 미치는 영향을 살펴보고, 연 구에 참여한 아동 부모의 앱을 이용한 중재에 대한 교육 효과 와 만족도에 대해서 조사하였다.

본 연구에서 인공와우 아동의 회기별 청각기억 점수를 살펴 본 결과, 대상 아동 모두 마지막 회기에서 청각기억 점수가 첫 번째 회기에 비해서 향상되었으며, 청각기억 점수의 향상 정도
에는 개인 간에 차이를 보였다. 이러한 개인 간 차이는 부모의 모바일 러닝에 대한 관심과 가정에서의 중재 참여의 적극성에 영향을 많이 받은 것으로 보인다. 즉, 부모가 모바일 러닝에 대 한 관심이 높고 가정에서 중재를 충실하게 진행한 경우에 아동 의 청각기억 향상 폭이 크게 나타났다. 청각기억 점수의 향상 정도가 작았던 아동 $\mathrm{A}$ 의 경우, 연령이 어리고 언어능력이 낮아 서 앱 활동 내 단어를 습득하는 과정이 필요하였으며, 부모가 모바일 러닝에 대한 인식이 낮아서 가정에서 앱 중재를 적극적 으로 하지 않았다. 반면에, 아동 $\mathrm{B}$ 와 $\mathrm{C}$ 의 청각기억 점수는 중 재 초반에 크게 향상되어 유지되는 경향을 보였다. 아동 $\mathrm{B}$ 와 $\mathrm{C}$ 의 부모는 오리엔테이션 당시부터 모바일 러닝에 대한 관심이 높았으며, 중재 기간 동안 가정에서도 지속적으로 앱을 이용하 여 자녀와 상호작용을 하면서 청각기억 앱 활동을 했다고 보고 하였다. 이러한 결과는 청능재활 기관에서 진행하는 전문가에 의한 중재 외에도 가정에서 부모가 앱과 같은 청능재활 도구를 
사용함으로써 청능재활 효과를 높일 수 있다는 것을 의미한다. 부모에 의한 가정 중재의 긍정적인 효과는 선행 연구(Cheon \& Yim, 2016; Lee, 2008a; Lee \& Seok, 2006)에서 강조한 바 있 다. Lee \& Seok(2006)과 Lee(2008a)는 체계적인 부모교육을 통해서 가정에서 부모와 인공와우 아동과의 상호작용 능력을 향상시켰다고 하였으며, Cheon \& Yim(2016)은 앱을 이용한 부모교육으로 부모와 자폐범주성 장애 아동과의 발화 횟수와 반응 비율을 증가시킬 수 있었다고 보고하였다. 전문가의 직접 적인 중재와 함께 부모가 인공와우 아동에게 제공하는 중재를 통해서 청능재활 효과는 더 높아질 수 있으며, 가정에서 부모가 활용할 수 있는 다양한 청능재활 도구의 개발을 통해서 부모가 아동의 청능재활에 관심을 가지고 더 적극적으로 참여하도록 유도할 수 있을 것으로 생각한다.

앱을 이용한 중재 전과 후의 청각기억 점수의 차이를 살펴본 결과, 중재 후의 청각기억 점수가 중재 전에 비해서 유의하게 향상되었다. 이러한 결과는 청각장애 및 다른 장애 아동에게 적용한 관련 연구들의 결과와 일치한다. Kronenberger et al. (2011)은 인공와우 아동의 청각기억폭과 처리 속도가 정상청력 아동에 비해서 현저하게 낮다는 점에 초점을 맞추어 인공와우 아동 $(\mathrm{n}=9)$ 을 대상으로 가정 내 컴퓨터를 이용하여 작업기억 (working memory) 중재를 5주간 실시한 결과, 인공와우 아동 의 구어와 비구어적인 청각기억이 향상되었으며 부모도 중재에 대해 긍정적인 효과를 지각하였다고 보고하였다. Kim \& Yim (2015)은 어휘발달장애 아동 $(\mathrm{n}=6)$ )을 대상으로 작업기억 중재 를 5 주간 실시한 결과, 단어회상 능력이 중재 전에 비해서 유의 하게 향상되었다. 인공와우 아동의 청각기억폭이 수용언어 능 력과 상관이 높다고 보고한 Dawson et al.(2002)의 연구를 토 대로 볼 때, 인공와우 아동에게 청각기억 중재를 실시하여 효 과가 있었다는 본 연구 결과는 임상적으로 시사하는 바가 있 다. 즉, 청각장애 아동의 말-언어 발달에 중요한 청각기억이 집 중적인 중재로 향상될 수 있었으므로, 청능재활에서 청각기억 을 목표로 중재를 진행하고 말-언어 발달에 긍정적인 영향을 미칠 수 있도록 해야 함을 의미한다. 그리고 청능재활 전문가는 청각기억 향상을 위해서 사용한 기존의 청능재활 콘텐츠 외에 도 다양한 청능재활 도구를 활용함으로써, 청각장애 아동이 중 재 활동에 참여하고 몰입하는 데 도움을 줄 수 있도록 해야 할 것이다.

사전-사후 청각기억 검사의 점수를 목록별로 살펴보면, 범주 와 비범주 목록의 청각기억 점수는 중재 후에 모두 향상되었으 나 범주 목록의 청각기억 점수 변화만이 통계적으로 유의한 차 이를 보였다. 정상청력 성인과 아동의 단어회상과 관련된 선행 연구(Monnier \& Bonthoux, 2011; Poirier \& Saint-Aubin, 1995)에서 연령대에 상관없이 의미 범주의 단어를 비범주 단어
에 비해서 더 잘 회상하는 것으로 보고하였다. Jang(2012)이 말-언어 발달이 정상 범주에 있는 인공와우 아동 $(\mathrm{n}=22)$ 을 대 상으로 의미적 단어 기억 과제를 실시한 결과에서도 비범주 목 록에 비해서 범주 목록의 단어에 대한 자유 회상을 더 많이 하 는 것으로 나타났다. 이러한 결과는 인공와우 아동도 정상청력 아동과 동일하게 장기기억(long-term memory)의 단어-의미 간의 지식을 활용하여 단기적인 청각기억을 유지하려는 경향 이 있다는 것을 의미한다. 즉, 장기기억에서 가지고 있는 단어 지식이 청각적으로 제시된 단어의 단기기억이 지워지지 않도록 단어-의미 표상(representation)과 상호작용을 하여 계속 활성 화하도록 돕는 것이다(Monnier \& Bonthoux, 2011). 본 연구에 서 인공와우 아동의 청각기억의 중재 효과를 범주와 비범주 목 록으로 구분하여 살펴봄으로써, 인공와우 아동의 청각기억 능 력이 발달되어 가는 과정에서 장기기억의 단어 의미의 유사성 과 단어-의미 간 지식을 활용하고 있다는 것을 확인할 수 있었 다. 이러한 결과는 임상 현장에서 청능재활 전문가가 청각기억 중재에 필요한 단어를 준비할 때, 제시하는 단어 간의 유사성 과 범주를 고려하여 난이도를 설정할 필요가 있음을 시사한다.

본 연구에서 앱을 이용한 청각기억 중재의 긍정적인 효과는 모바일 러닝이 청각장애 아동의 청능재활에서도 확장될 수 있 음을 의미한다. 청각장애 성인의 청능재활에 모바일 러닝을 활 용한 연구 사례가 발표된 바가 있으며, 그 연구 결과에서도 스 마트폰을 매개로 진행한 중재가 청각장애인의 어음인지와 독 화(lip-reading) 향상에 도움이 되었다. Yu et al.(2014)이 어음 인지 향상을 위한 콘텐츠를 스마트폰 청능훈련 앱으로 개발하 여 청각장애 성인 $(\mathrm{n}=1)$ 에게 4주 동안 중재를 실시한 결과, 자 음과 문장에서 유의미한 어음인지도 향상을 보였다. $\operatorname{Lim} \&$ $\operatorname{Sim}(2016)$ 의 선천성 농 성인(n = 5)에게 스마트폰을 이용하여 독화 지도를 3개월 동안 실시한 결과, 대상자의 문장 독해 능력 이 중재 전에 비해 유의미하게 향상되었다. Yu et al.(2014)과 $\operatorname{Lim} \& \operatorname{Sim}(2016)$ 은 모바일을 이용한 중재가 청각장애인이 시 간과 공간의 제약 없이 학습환경을 스스로 조성할 수 있는 장 점이 있다고 언급하면서, 모바일과 앱은 청각장애인이 청능재 활에 지속적으로 참여할 수 있도록 도움을 줄 수 있어서 효과 적인 청능재활 도구가 될 수 있다고 강조하였다. 현재까지 청각 장애 아동을 대상으로 앱을 이용한 중재가 진행되어 보고된 연 구사례를 찾아볼 수는 없지만, 모바일 앱을 이용한 중재가 의 사소통에 어려움을 지닌 장애 아동에게 적용되어 긍정적인 효 과가 있다고 보고된 바는 있다(Cho \& Kim, 2013; Choi \& $\operatorname{Kim}, 2015)$. Choi \& Kim(2015)은 지적장애 아동 $(\mathrm{n}=3)$ 에게 메신저 앱을 이용하여 보완대체 의사소통(augmentative and alternative communication)을 실시하여, 대상 아동이 앱에 대 한 흥미와 의사소통 자신감이 향상된 것뿐만 아니라 어휘 다양 
도(type-token ratio)와 내용어(content words) 사용 빈도가 향 상되었다고 보고하였다. Cho \& $\operatorname{Kim}(2013)$ 이 지적장애 학생(n = 9)에게 9주 동안 동화 어플리케이션 중재를 실시한 결과, 읽 기 유창성, 독해, 읽기 태도가 향상되었다. 이렇듯 모바일 러닝 이 장애에 상관없이 효과적인 도구로 사용될 수 있는 것은 시 공간의 한계성을 극복한 것 외에 교수 활동의 제약이 적으며 유희성 증진에 도움을 주기 때문으로 생각된다. 즉, 모바일 러 닝은 일반적인 교수 학습 활동에 비해 친근하고 다양한 경험 활동의 구성이 자유로우며 캐릭터와 애니메이션과 같은 유희성 을 아동에게 제공할 수 있는 것이다(Hagr et al., 2016; Kim et al., 2015). 본 연구에서도 모바일 러닝의 장점이 인공와우 아동 에게 앱을 이용하여 청각기억 중재를 하는 데 적용되어, 대상 아동이 청각기억 앱 활동에 흥미를 가지고 몰입하는 데 긍정적 인 영향을 미쳐서 중재 효과가 나타난 것으로 볼 수 있겠다.

본 연구에서 실시한 앱 중재에 대한 부모 설문에서는 교육 효과에 대한 평가가 교육 만족도보다 높게 나타났다. Lee \& Kwon(2014)은 교육용으로 개발된 앱과 소프트웨어는 대상 아 동의 학습 동기를 자극시켜 학습 능률을 높여주기 때문에 긍정 적인 교육 효과를 줄 수 있다고 하였다. 아동의 흥미를 끄는 캐 릭터와 애니메이션이 앱으로 구현되기 때문에 아동이 앱의 교 육 활동에 집중하고 몰입될 수 있으므로, 부모 입장에서는 앱 을 이용한 중재가 아동의 학습에 효과가 있다고 평가하였을 것 이다. 부모 설문 결과를 세부적으로 살펴보면, 부모의 모바일 러닝에 대한 인식과 경험, 가정 지도에 대한 부담이 본 연구에 서 실시한 앱 중재에 대한 교육 효과와 만족도와 관련이 있을 것으로 사료된다. 아동 $\mathrm{A}$ 의 부모는 앱을 이용한 중재에 대한 교육 효과와 만족에서 낮은 평가를 하였으며, 아동 $\mathrm{B}$ 와 $\mathrm{C}$ 의 부 모는 두 영역에서 높은 평가를 하였다. 아동 $\mathrm{A}$ 의 부모는 모바 일 러닝의 효과 외에 스마트폰 자체가 아동에게 미칠 수 있는 부정적인 영향에 대한 염려를 하고 있었으며, 중재 동안 가정에 서도 아동과 상호작용하면서 학습 활동을 해야 한다는 부담이 크다고 언급하였다. 반면에, 아동 $\mathrm{B}$ 와 $\mathrm{C}$ 의 부모는 모바일 러닝 에 대한 관심이 높아서 중재 동안 가정에서도 아동과 상호작용 하면서 적극적으로 앱을 사용하였으며, 아동 $\mathrm{C}$ 의 부모는 본 연 구에 참여하기 전에 교육용 앱을 이용하여 아동의 학습을 촉 진해본 경험을 가지고 있었다. 이는 부모의 스마트미디어의 활 용에 대한 긍정적인 인식, 관심, 경험이 앱을 이용한 중재의 교 육 효과와 만족도을 높일 수 있으므로, 모바일 러닝에서 부모 의 역할이 중요하다는 의미한다. 향후 스마트 기기의 활용이 다 양한 측면으로 이루어짐에 따라 모바일 러닝이 장애 아동의 교 육과 무관하지 않기 때문에, 앱을 이용한 중재가 청각장애 아 동의 듣기, 말-언어, 의사소통에 긍정적인 영향을 미칠 수 있도 록 부모와 아동을 대상으로 올바른 스마트폰의 사용과 부모의
역할에 대한 올바른 교육을 제공할 수 있도록 부모교육 프로 그램이 개발되어야 할 것이다.

본 연구는 인공와우 아동에게 앱을 이용한 청각기억 중재의 효과를 확인함으로써 청능재활 분야에서의 청각장애 아동을 대상으로 한 모바일 러닝의 가능성에 대해 모색할 수 있었으며, 아동을 대상으로 한 모바일 러닝의 경우 부모의 역할에 따라 중재 효과가 더 커질 수 있다는 것을 확인하였다. 본 연구의 제 한점과 후속연구를 위한 제안은 다음과 같다. 첫째, 본 연구에 서는 동일한 성별인 인공와우 아동 3 명을 대상으로 중재를 실 시하여 실험 집단의 대상자 수가 적었다. 자발적으로 연구 참여 를 희망한 부모의 동의를 얻어 중재를 실시하여, 대상 아동의 연령, 인공와우이식 연령, 인공와우 착용기간, 언어 능력, 인지 능력 등의 변수를 통제하지 못하였다. 특히, 작업기억, 지능 등 과 같은 인지 능력을 측정하지 못하여, 중재 효과에서 나타난 개인 간 차이에 대해서 충분히 설명하지 못하였다. 둘째, 본 연 구는 사전-사후 평가 기간을 제외하고 5 주 동안 연구자에 의 한 직접 중재와 부모의 가정 중재로 진행되었다. 대상 아동의 교육과 치료 스케줄로 인해서 주 1 회의 시간만 허용되어서 직 접 중재의 기간을 길게 진행하지 못한 한계를 지니고 있다. 셋 째, 대상 아동의 낮은 언어 능력을 고려하여 중재와 사전-사후 평가의 단어를 선정하는 과정에서, 일부 단어(예: 참외, 바나나) 가 중복되어 사용된 제한점을 지니고 있다. 넷째, 본 연구에서 는 한 집단에서 중재를 실시하고 중재 동안과 사전-사후 평가 에서의 청각기억 점수 차이를 비교하여 중재 효과를 살펴보았 다. 따라서, 후속 연구에서는 대상자 수를 확대하고 특정 연령 대로 통제할 필요가 있으며, 중재와 평가에 사용하는 단어에 대해서 엄격하게 통제하며, 앱 중재를 실시한 실험 집단 외에 다른 방법으로 청각기억 중재를 실시한 통제 집단을 설정하여 연구의 내적 타당도를 높임으로써 중재 효과를 확실히 검증할 필요가 있겠다. 한편, 후속 연구에서는 제시되는 단어의 의미 유사성과 범주에 따른 청각장애 아동의 청각기억 특성에 대해 진행하여, 청각장애 아동의 청각기억 특성을 반영한 청각기억 중재 프로그램을 개발할 필요도 있겠다.

중심 단어 : 청능재활·스마트폰 어플리케이션·청각기억· 인공와우이식·아동.

\section{Acknowledgments}

본 연구는 중소기업청의 기술혁신개발사업의 일환으로 수행하였 음(C0276689, 청각장애 아동의 의사소통 능력 향상을 위한 언어치 료 어플리케이션 개발).

\section{REFERENCES}

American Speech-Language-Hearing Association (ASHA). (2017, January 5). Cochlear implants. Retrieved from http://www.asha.org/policy/ 
TR2004-00041/.

Baddeley, A. (2003). Working memory and language: An overview. Journal of Communication Disorders, 36(3), 189-208.

Baek, S. S. \& Lee, J. H. (2016). Development of crossword puzzles for auditory training. Audiology and Speech Research, 12(2), 103-108.

Barker, L. J. (2003). Computer-assisted vocabulary acquisition: The CSLU vocabulary tutor in oral-deaf education. Journal of Deaf Studies and Deaf Education, 8(2), 187-198.

Blamey, P. J., Sarant, J. Z., Paatsch, L. E., Barry, J. G., Bow, C. P., Wales, R. J., et al. (2001). Relationships among speech perception, production, language, hearing loss, and age in children with impaired hearing. Journal of Speech, Language, and Hearing Research, 44(2), 264-285.

Burkholder, R. A. \& Pisoni, D. B. (2003). Speech timing and working memory in profoundly deaf children after cochlear implantation. Journal of Experimental Child Psychology, 85(1), 63-88.

Cho, Y. J. \& Kim, Y. W. (2013). The effect of reading activity through children's story applications on reading ability and reading attitude of students with intellectual disabilities. Journal of Intellectual Disabilities, 15(3), 125-145.

Cheon, S. H. \& Yim, D. S. (2016). The effects of parental education using an utterance-analyzing application on initiation, response, and turntaking in conversations between children with ASD and their parents. Journal of Speech and Hearing Disorders, 25(3), 87-103.

Choi, H. S. \& Kim, N, J. (2015). The effects of the language mediation program using K-application in smart phone on language ability for students with intellectual disabilities. Journal of Mental Retardation, 17(1), 133-152.

Cole, E. B. \& Flexer, C. (2011). Hearing aids, cochlear implants, and FM system. In E. B. Cole \& C. Flexer. Children with Hearing Loss Developing Listening and Talking: Birth to Six (2nd ed.) (pp. 117-166). San Diego, CA: Plural Press.

Dawson, P. W., Busby, P. A., McKay, C. M., \& Clark, G. M. (2002). Shortterm auditory memory in children using cochlear implants and its relevance to receptive language. Journal of Speech, Language, and Hearing Research, 45(4), 789-801.

Fu, Q. J. \& Galvin, J. J. (2007). Computer-assisted speech training for cochlear implant patients: feasibility, outcomes, and future directions. Seminars in Hearing, 28(2). http://dx.doi.org/10.1055/s-2007-973440.

Hagr, A., Garadat, S. N., Hassan, S. M., Malki, K., Al Ohali, Y., Al Ghamdi, N., et al. (2016). The effect of the arabic computer rehabilitation program "Rannan" on sound detection and discrimination in children with cochlear implants. Journal of the American Academy of Audiology, 27(5), 380-387.

Houston, D. M. \& Miyamoto, R. T. (2010). Effects of early auditory experience on word learning and speech perception in deaf children with cochlear implants: implications for sensitive periods of language development. Otology and Neurotology, 31(8), 1248-1253.

James, D., Rajput, K., Brinton, J., \& Goswami, U. (2008). Phonological awareness, vocabulary, and word reading in children who use cochlear implants: Does age of implantation explain individual variability in performance outcomes and growth? Journal of Deaf Studies and Deaf Education, 13(1), 117-137.

Jang, M. Y. \& Song, J. E. (2015). An exploratory study on mothers with infants and preschool children smart device use: Focusing on usage for child care. Journal of Learner-Centered Curriculum and Instruction, 15(12), 1-21.

Jang, S. (2012). Semantic short-term memory according to category knowledge in children with cochlear implnat (unpublished master's thesis). Daegu University, Daegu.

Jutras, B. \& Gagné, J. P. (1999). Auditory sequential organization among children with and without a hearing loss. Journal of Speech, Language, and Hearing Research, 42(3), 553-567.

Kim, J. M., Cha, T. H., Kim, H. H., Lee, M. H., Yi, J. M., \& Jang, Y. H. (2015). Effectiveness and trends in application based intervention for students with disabilities. The Journal of Special Education: Theory and Practice, 16(3), 225-249.

Kim, K. Y., Cho, K. S., Hwang, E. M., Kang, H. J., \& Jang, S. J. (2014). The mothers' perceptions about educational value of smartphone usage. Journal of Child Care and Education, 86, 187-207.

Kim, M. J., Pae, S., \& Park, C. I. (2007). Assessment of Phonology for Children (APAC). Incheon: Human Brain Research \& Consulting Co.

Kim, S. \& Yim, D. (2015). Study of working memory intervention in children with delay in vocabulary development: Effects on working memory and language ability. Communication Sciences and Disorders, 20(4), 469-489.

Kim, Y., Hong, K., Kim, K., Chang, H., \& Lee, J. (2009). Receptive and Expressive Vocabulary Test (REVT). Seoul: Seoul Community Rehabilitation Center.

Kronenberger, W. G., Pisoni, D. B., Henning, S. C., Colson, B. G., \& Hazzard, L. M. (2011). Working memory training for children with cochlear implants: A pilot study. Journal of Speech, Language, and Hearing Research, 54(4), 1182-1196.

Lee, E. K. (2008a). The effect of language communication ability of home language intervention in parents for their children with cochlear implant. Journal of Speech-Language and Hearing Disorders, 17(2), 155169.

Lee, E. K. \& Seok, D. I. (2006). The contents of parent education about parent participation style for children with speech-language disorder. Journal of Speech and Hearing Disorders, 15(4), 33-48.

Lee, M. Y. (2008b). The 5th Dong-A Hearing Symposium. Diagnostic Therapy for Infants with Hearing Impairment. Busan, Korea.

Lee, M. Y., Shin, J. C., Kim, H. H., \& Kim, L. S. (2009). Open-set monosyllabic speech perception test for preschool children. Korean Journal of Otorhinolaryngology-Head and Neck Surgery, 52(4), 312-321.

Lee, S. K. \& Kwon, M. H. (2014). A study on the awareness of elementary school teachers and students about the smart education and its improvement plan. Journal of Communication Science, 14(2), 258-294.

Lee, S. M., Seo, H. A., \& Han, H. J. (2014). Use of smart devices of infants and preschool-children and their mothers' perceptions. Korean Journal of Childcare and Education, 10(2), 111-131.

Lee, Y. (2016). Parental current practice and needs in smart device applications for children with cochlear implants. Audiology and Speech Research, 12(4), 269-279.

Lee, Y. (2017). Mobile application development for improving auditory memory skills of children with hearing impairment. Audiology and Speech Research, 13(1), 50-61.

Lee, Y., Lee, S., \& Sung, M. (2015). Analysis of mobile application trends for speech and language therapy of children with disabilities in Korea. Journal of the Korean Society of Speech Sciences, 7(3), 153-163.

Lee, Y., Yim, D., \& Sim, H. (2012). Phonological processing skills and its relevance to receptive vocabulary development in children with early cochlear implantation. International Journal of Pediatric Otorhinolaryngology, 76(12), 1755-1760.

Lim, J. \& Park, E. (2012). Development and research trends of application as the smart education media for ASD. Journal of the Korean Association for Persons with Autism, 12(1), 93-117.

Lim, Y. R. \& Sim, H. S. (2016). Effect of speechreading telepractice intervention using smartphone on speechreading ability of young deaf adults. Journal of Special Education Research, 15(3), 125-154.

Monnier, C. \& Bonthoux, F. (2011). The semantic-similarity effect in children: Influence of long-term knowledge on verbal short-term memory. British Journal of Developmental Psychology, 29(4), 929-941.

Nakeva von Mentzer, C., Lyxell, B., Sahlén, B., Dahlström, Ö., Lindgren, M., Ors, M., et al. (2014). Computer-assisted reading intervention with a phonics approach for children using cochlear implants or hearing aids. Scandinavian Journal of Psychology, 55(5), 448-455.

Park, W. \& Yim, D. (2015). The effectiveness of parental education via smartphone application on number of utterances and initiation ratio. Communication Sciences and Disorders, 20(4), 500-509.

Poirier, M. \& Saint-Aubin, J. (1995). Memory for related and unrelated words: Further evidence on the influence of semantic factors in immediate serial recall. The Quarterly Journal of Experimental Psychology, 48(2), 384-404.

Spencer, P. \& Delk, L. (1989). Hearing-impaired students' performance on 
tests of visual processing: Relationships with reading performance. American Annals of the Deaf, 134(5), 333-337.

Sweetow, R. W. \& Sabes, J. H. (2006). The need for and development of an adaptive listening and communication enhancement $\left(\mathrm{LACE}^{\mathrm{TM}}\right)$ program. Journal of the American Academy of Audiology, 17(8), 538-558.

Wood, K. L. (2013). A critical period of development for auditory memory and the auditory scaffolding hypothesis (unpublished master's thesis). Washington University School of Medicine, St. Louis.

Yu, J., Chun, H., Song, C. G., \& Han, W. (2014). Case study of speech perception enhancement in hearing-impaired adult by auditory training program of mobile device. Audiology, 10(2), 158-168. 


\section{APPENDICES}

Appendix 1. Pre- and Post-Intervention Test for Auditory Memory

아동 이름:

생활연령(생년월일):

검사 날짜:

〈범주 목록〉

\begin{tabular}{|c|c|c|c|}
\hline 범주 목록 & 단 어 & 아동 반응 & 순차적 회상 \\
\hline 과일 & 참외, 귤, 포도, 복숭아, 바나나 & & \\
\hline 의류 & 수영복, 목도리, 모자, 티, 잠바 & & \\
\hline 음식 & 초콜릿, 빵, 라면, 자장면, 김치 & & \\
\hline 탈것 & 버스, 기차, 자동차, 배, 비행기 & & /5 \\
\hline 동물 & 원숭이, 새, 돼지, 고래, 고양이 & 점수 & \\
\hline \multicolumn{2}{|r}{} & & \\
\hline
\end{tabular}

\section{〈비범주 목록〉}

\begin{tabular}{|c|c|c|}
\hline 단어 & 아동 반응 & 순차적 회상 \\
\hline 지우개, 주스, 목걸이, 공, 오리 & & \\
\hline 비누, 연필, 젓가락, 자전거, 물 & & \\
\hline 토마토, 운동화, 배, 수박, 치마 & & \\
\hline 딸기, 밥, 색연필, 토끼, 반바지 & & \\
\hline 다람쥐, 파, 오렌지, 장갑, 공책 & 점수 & \\
\hline \multicolumn{2}{|r}{} \\
\hline
\end{tabular}


Intervention Using Applications for Children with Cls

Appendix 2. Parent Questionnaire on the Intervention Using Applications

교육 효과에 관한 설문 문항 (1) 전혀 그렇지 않다, (2) 그렇지 않다, (3) 보통이다, (4) 그렇다, (5) 매우 그렇다)

\begin{tabular}{|c|c|c|c|c|c|c|}
\hline 번호 & 설문 문항 & \multicolumn{3}{|c|}{ 응 } & & \\
\hline 1 & $\begin{array}{l}\text { 앱 활동의 교육목표('청각기억')가 정확하다고 } \\
\text { 생각하십니까? }\end{array}$ & $\begin{array}{l}(1) \\
+\end{array}$ & (2) & (3) & (4) & $\begin{array}{c}(5) \\
+1\end{array}$ \\
\hline 2 & $\begin{array}{l}\text { 앱의 학습목표('청각기억')가 교육적 가치를 지니고 있다고 } \\
\text { 생각하십니까? }\end{array}$ & (1) & $\stackrel{(2)}{1}$ & (3) & (4) & + \\
\hline 3 & $\begin{array}{l}\text { 앱 활동의 교육 수준 난이도가 자녀에게 적절하다고 생각 } \\
\text { 하십니까? }\end{array}$ & (1) & (2) & (3) & (4) & (5) \\
\hline 4 & 앱 활동이 난이도별로 잘 제시되어 있다고 생각하십니까? & (1) & $\stackrel{(2)}{1}$ & (3) & (4) & + \\
\hline 5 & $\begin{array}{l}\text { 앱 활동에서 나오는 어휘가 자녀에게 친숙하고, 적절하다고 } \\
\text { 생각하십니까? }\end{array}$ & (1) & (2) & (3) & (4) & (5) \\
\hline 6 & $\begin{array}{l}\text { 앱에서 의미있는 음성과 그림이 함께 제시됨과 동시에, } \\
\text { 피드백*이 잘 이루어진다고 생각하십니까? }\end{array}$ & (1) & (2) & (3) & (4) & (5) \\
\hline 7 & $\begin{array}{l}\text { 앱에서 자녀의 수행에 따라 적절하게 피드백을 제공한다고 } \\
\text { 생각하십니까? }\end{array}$ & (1) & $\stackrel{(2)}{1}$ & (3) & (4) & (5) \\
\hline 8 & $\begin{array}{l}\text { 청각기억 목표 성취를 위해 다양한 활동을 경험할 수 } \\
\text { 있다고 생각하십니까? }\end{array}$ & (1) & (2) & (3) & (4) & (5) \\
\hline 9 & $\begin{array}{l}\text { 자녀의 흥미 유발을 위해 게임요소(캐릭터, 애니메이션 등) } \\
\text { 를 잘 활용하고 있다고 생각하십니까? }\end{array}$ & (1) & (2) & (3) & (4) & (5) \\
\hline 10 & $\begin{array}{l}\text { 앱 활동이 자녀의 경험과 연결되어 친숙하다고 } \\
\text { 생각하십니까? }\end{array}$ & (1) & (2) & (3) & (4) & (5) \\
\hline 11 & $\begin{array}{l}\text { 자녀의 활동이력을 살펴보면서 앱을 통해 자녀의 } \\
\text { 청각기억이 좋아졌다고 생각하십니까? }\end{array}$ & $\begin{array}{l}\text { (1) } \\
\mid\end{array}$ & $\begin{array}{l}\text { (2) } \\
1\end{array}$ & $\begin{array}{l}\text { (3) } \\
1\end{array}$ & (4) & (5) \\
\hline
\end{tabular}

*'피드백'이란 자녀의 수행에 따라 정/오반응을 제공하는 것으로, 활동 안에서 아동의 수행이 정반응일 때는 웃고, 오반응일 때는 울 상을 짓는 것을 말합니다. 
교육 만족도에 관한 설문 문항 (1) 전혀 그렇지 않다, (2) 그렇지 않다, (3) 보통이다, (4) 그렇다, (5) 매우 그렇다)

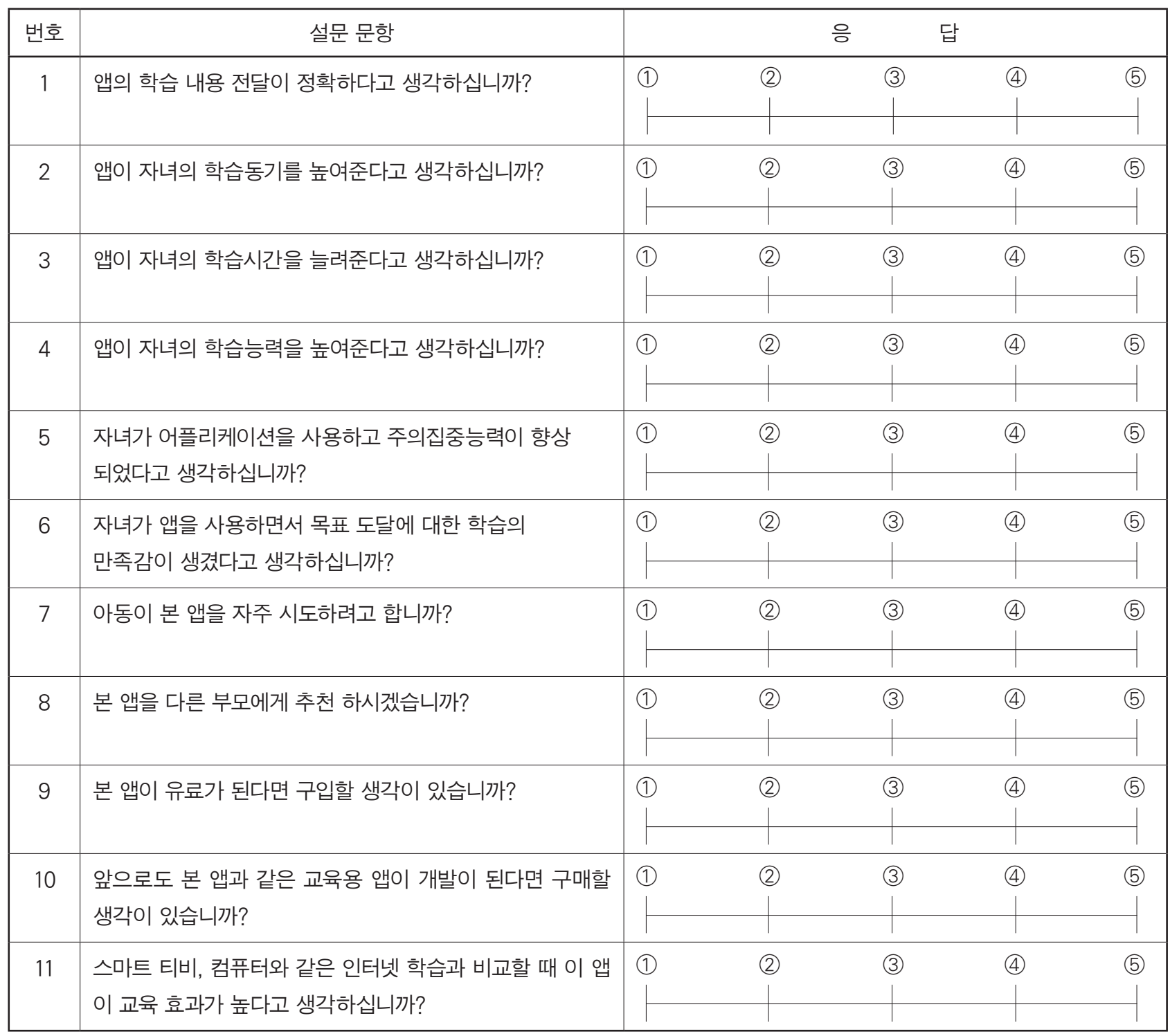


ASR

Intervention Using Applications for Children with Cls

Appendix 3. Fidelity Checklist for Intervention

\begin{tabular}{|c|c|c|c|}
\hline 항목 & 번호 & 문 & $\begin{array}{c}\text { 충실도 } \\
\text { (예/아니오) }\end{array}$ \\
\hline \multirow[t]{2}{*}{ 중재 계획 } & 1 & 연구자는 중재를 계획된 일정에 따라 실시하였는가? & \\
\hline & 2 & 연구자는 중재를 계획된 내용에 따라 실시하였는가? & \\
\hline \multirow[t]{6}{*}{ 중재 실행 } & 3 & 연구자는 아동에게 앱 활용 방법을 충분히 알려주어 이해를 도왔는가? & \\
\hline & 4 & $\begin{array}{l}\text { 연구자는 부모에게 중재 목표를 충분히 설명하고, 중재에 사용되는 앱에 대한 이해를 } \\
\text { 도왔는가? }\end{array}$ & \\
\hline & 5 & 연구자는 아동에게 듣고 수행하기 전략을 충분히 알려주고 이해를 도왔는가? & \\
\hline & 6 & 연구자는 아동이 앱을 스스로 사용할 수 있도록 충분한 이해를 도왔는가? & \\
\hline & 7 & 연구자가 아동 혹은 부모에게 직접 시연하여 이해를 도왔는가? & \\
\hline & 8 & 앱 활동에서 아동의 반응을 촉진하고 피드백을 제공하였는가? & \\
\hline \multirow[t]{2}{*}{ 중재 평가 } & 9 & 회기마다 아동의 앱의 활용시간과 수행력을 확인하였는가? & \\
\hline & 10 & 중재 후, 부모상담을 통해 아동의 수행력에 대한 피드백을 제공하였는가? & \\
\hline
\end{tabular}

